\title{
Financial Health Check-up of Pokhara Royal Co-operative Soci- ety Limited in the Framework of PEARLS
}

\author{
Keshar J. Baral
}

\begin{abstract}
Using the data set disclosed in annual reports and extracted from the ledger of Pokhara Royal Cooperative Society Limited (PRCSL), this paper examines the financial health of PRCSL in the framework of PEARLS. The health check up conducted on the basis of publicly available financial data concludes that PRCSL has not earned enough to pay up the return on member share capital and build up the institutional capital as the second line of defense for saving deposits of member-clients. In addition, the perusal of indicators of different components of PEARLS indicates that the financial health of PRCSL is not so sound.
\end{abstract}

Key words: cooperative, PEARLS, WOCCU

THE HISTORY OF CO-OPERATIVE SOCIETY dates back to 1956 A.D in which year the then government incorporated Bakhan Saving and Credit Cooperative Ltd in Rapti Valley, Chitawan by issuing executing order for its legal validity (Baral 2005). The Thirty-Year Panchayat regime also attempted to promote cooperatives by enforcing the Cooperative Act, 1959 (2016 B.S) and Cooperative Regulation, 1961 (2018 B.S). However, cooperatives became burdensome to the then government due to the weak management, want of autonomy and unscientific accounting system of saving and credit. After the restoration of democracy in 1990, the then government considered cooperatives as a means of poverty alleviation. It enforced new Cooperative Act, 1991 (2048 B.S) and Cooperative Regulation, 1992 (2049 B.S.) and repealed both act and regulation of Panchayat regime. The new cooperative act is considered one of the best democratic cooperative acts of the world. But due to the undemocratic practices and environment in democratic system, in most of the cases, cooperatives have turned out as an intermediary to transfer the money from poor to rich. The democratic government speeded up the liberalization of financial sector. In liberalized financial environment, saving and credit cooperatives grew like mushroom especially in urban and suburban areas of the country. PRCSL is one of these cooperatives. Royal Cooperative Society Ltd. (RCSL) was incorporated in 1998 under the Cooperative Act, 1991 in Kathmandu, Nepal. It established its Central Office in Kathmandu and Regional Office in Pokhara. In addition, it opened branch offices in Lalitpur, Narayangarh, Hetauda, Syangja, and Duligauda, Tanahun. The fourth annual general meeting of RCSL resolved dissolution to convert its central office, regional office and all branches as a autonomous cooperative with effect to the circulation of Cooperative Department of the then government to localize the branches of cooperatives and develop an autonomous institution in 2002. As a result of this resolution, PRCSL was incorporated to the District Cooperative Office, Kaski in 2002. Since then it is working as an autonomous saving and credit cooperative in Pokhara.

In many instances, management of cooperatives decamped with the saving of the poor. Out of thousands of saving and credit cooperatives, only few cooperatives are under 
the jurisdiction of monitoring authority, Nepal Rastra Bank (NRB). ${ }^{1}$ Nepal Government founded on the people mandate given by the Second People's Movement also has retained the same policy of the previous government- establishment of second-tier institution for effective regulation, inspection, and supervision of financial cooperatives and nongovernmental organizations registered under Cooperatives Act and Societies Registration Act (Government of Nepal 2006). At present, NRB does the offsite and onsite supervision of cooperatives licensed for limited banking services. It regulates and supervises the cooperatives under its jurisdiction on the basis of same supervision parameters-minimum core capital, minimum capital funds, limit of funds collection, minimum cash reserve, minimum liquid assets, classification of loan and advance and loan loss reserve, limit of single borrower, used for other financial institutions. It has adopted CAMELS (capital adequacy, asset quality, management quality, earning, liquidity, and sensitivity to market) rating system to evaluate the financial institutions except to micro finance. NRB has not included cooperatives in micro finance industry (NRB 2006). So, it implies that it is using the same rating system to check-up the financial condition of the cooperatives also. But, CAMELS rating system does not evaluate the financial structure of the balance sheet and it consider the growth rate of the total assets. So, since 1990, the World Council of Credit Unions, Inc (WOCCU) has been using PEARLS (protection, effective financial structure, asset quality, rates of return and costs, liquidity and sign of growth) to monitor the performance of credit unions and check-up their financial health (Richardson 2002). In this article, financial health check-up of PRCSL has been conducted in the framework of PEARLS.

\section{Rationale of Regular Health Check-up of Saving and Credit Cooperatives}

Not only the saving and credit cooperatives (cooperative with limited banking service) but also any financial institutions (FIs) require for regular health check-up to maintain the confidence of private sector in financial system of the country and protect the interest of depositors, lenders, shareholders/members and other stakeholders. The gravity of the importance of sound financial health of an FI has increased tremendously after the international financial turmoil of the second half of 1990s. International monetary authorities such as International Monetary Fund and the World Bank have underpinned the need of healthy financial sector to build up the confidence of private sector in the liberalized financial system. They have directed their member countries to reform the financial sector and conduct the regular health check-up of FIs through onsite and offsite supervision. The World Bank and Asian Development Bank are supporting the projects run in the vein of reforming process of the financial sector of different countries. In Nepal, the World Bank is constantly providing the technical and financial support to reengineer NRB and restructure Nepal Bank Ltd. and Rastriya Banijya Bank (NRB 2005).

Health of financial sector depends on the health of individual FIs. In addition, individual FIs' health counts on the myriad macro and micro factors. Among the macro factors, political stability and the real sector growth are vital. The financial health of FIs can not sustain without the political stability and sustainable real sector growth with sound health. However, the intensity of contagious effect of these macro variables may vary from one individual FI to another. Therefore, health of any individual FI should be checked up regu-

\footnotetext{
${ }^{1}$ By Mid-January, 2006, the number of saving and credit cooperatives licensed by Nepal Rastra Bank was 19.
} 
larly to know the intensity of such effect.

Health of an individual FI is a function of multiple factors such as quality of its assets, liquidity position, capital base, management quality, market sensitivity, growth, financial structure and earnings. All these factors affect the different types of risk to an individual FI. Different types of risks: credit, interest rate, liquidity, market, off-balance sheet, foreign exchange, sovereign, technology, operational, insolvency, affect the health of an individual FI adversely if they are not managed in sustainable manner (Saunders and Cornett 2004). A number of factors such as quality of assets, financial market condition, foreign exchange market, composition of assets, financial health of its clients, profitability, capital adequacy, affect the degree of these risks. Financial health check-up of an individual institution should be made regularly to detect the adverse effect of these risks on its health. Micro-prudential indicators such as capital adequacy, asset quality, management soundness, earning and profitability, liquidity, sensitivity to market risk, and market based indicators like market price of financial instruments, credit ratings are used as indicators of the sound health of an individual FI (Evan and others 2000). In addition, sound financial structure, and sustainable growth rate also are considered as good indicators of any FIs. Financial health check-up is required, particularly for a saving and credit cooperative to find out the severe financial problems and attract the attention of management to resolve such problems. Ill financial health may threaten the safety and soundness of a cooperative. It may cause the financial loss to the members and adversely affect the member confidence in the saving credit cooperative and system as a whole. Therefore, regular financial health check-up of such a cooperative should be conducted to find out the severe problems and solve them before they threaten its safety and soundness, cause the financial loss to the members, and adversely affect the member confidence in it, and a cooperative system as a whole.

\section{Theoretical Prescription of PEARLS Framework}

There are many sets of financial ratio that can be employed to evaluate the performance and check up the financial health of FIs. Among them, CAMELS framework-developed by regulatory authority of the U.S banks, is the common method used for evaluating the soundness of FIs. A round table group comprising of MicroRate - a rating agency specializing in microfinance, Inter-American Development Bank, the Consultative Group to Assist the Poorest, the United States Agency for International Development, and two other rating agencies-MCRIL and PlaNet Rating, developed a set of commonly used performance indicators for microfinance institutions (MFIs). This set of performance indicators fall into four main categories - profitability, efficiency and productivity, asset quality/portfolio quality, financial management (Stauffenberg and others 2003). This set of indicators is commonly known by PEAF. CAMELS is not an appropriate tool for MFIs due to the earlier mentioned reasons. PEAF also does not consider the growth rate of the total assets. But PEARLS does away the deficiencies of both CAMELS and PEAF by incorporating the growth and financial structure related indicators. This is the reason why the WOCCU and its member countries are using this to monitor, supervise and check up the financial health of MFIs like credit unions and cooperatives. In addition, MFIs also are using PEARLS as a managerial tool to monitor and improve their performance. 
Protection (P): As the acronym-PEARLS, implies that this tool for monitoring the performance of MFIs has seven components. The first component-protection, is very crucial component. Here, protection refers to the safe of money of the member-client of MFIs. It is remarkable that every client should be member. Any body else can open the saving account and borrow the money only after receiving membership of the cooperative. So, every member is the client and every client is the member of a cooperative. Unless and until potential member-clients do not feel safe to deposit their money in a cooperative, they do not deposit their saving. Once they feel safe to deposit their saving, they put up their money in a cooperative and do not withdraw it. There may be cooperative run if member-clients feel unsafe to their saving. Protection to the saving of member-clients can be done by providing adequate protection to assets. So, the basic tenet of the new credit union model is adequate protection of assets. Protection can be provided by making adequate allowances for loan losses.

According to the WOCCU model, protection against loan losses is deemed adequate if a cooperative has sufficient provision to cover 100 percent of all loan delinquent for more than one year and 35 percent of all loans delinquent for 1-12 months (Richardson 2002). In Nepal, cooperatives licensed for limited banking services - collection of saving and lending the money, should have 1 percent of pass loan (loans and advances not past due and past due for maximum 3 months), 25 percent of substandard loan (loans and advances past due 3 months to 9 months), 50 percent of doubtful debt (loans and advances past due 9 months to 1 year), and 100 percent of bad debt (loans and advances past due more than 1 year) for loan loss provision (NRB 2002). But thousand of saving and credit cooperatives are out of the jurisdiction of NRB. So, most of the cooperatives do not have loan loss provision as per this directive.

Inadequate loan loss provision results in two undesirable results—inflated asset value and fictitious earnings. Loan loss provision is deducted from gross loan portfolio for accounting reporting. So, inadequate loan provision means deduction of less loan loss provision expense from gross loan portfolio and overstatement of the value of assets in the balance sheet. Loan loss provision expense is charged off to profit and loss account. Less loan loss provision expense charged to profit and loss account means the reported net income is overstated. Thus, inadequate loan loss provision inflates the asset value, overstates the earnings and risks the savings of members. In brief, saving is inadequately protected if loan provision is inadequate. The PEARLS system evaluates the adequacy of protection afforded to the cooperative by comparing the loan loss provision to amount of loan at risk. In this system, loan loss provision is considered as the first line of defense against non-performing assets. The degree of protection is measured by six different ratios- $\mathrm{P}_{1}, \mathrm{P}_{2}, \mathrm{P}_{3}, \mathrm{P}_{4}, \mathrm{P}_{5}$ and $\mathrm{P}_{6}$ (for detail see Appendix 1).

Effective Financial Structure (E): The financial structure determines growth potential, earnings capacity and overall financial strength of MFIs. In general, financial structure refers to the composition of different sources of resources. Unhealthy financial structure hinders the growth, and weakens the earnings capacity and financial strength of FIs. It may lead MFIs to the verge of liquidation or force the management to run away and cause the management to lose the confidence of member-clients. Healthy financial structure is one facet of the financial structure and effective use of the resources is another one. So, PEARLS 
system measures the effective financial structure in both financing of resources and effective use of the resources of MFIs. So, the ratios of different types of assets to total assets and different types of liabilities to total assets are worked out to measure the effective financial structure of MFIs (see Appendix 1).

According to PEARLS system, investment in net loan, liquid assets, financial assets, and non-financial investments should be in the range of 70-80 percent, 20 percent, 10 percent, and zero percent of total assets respectively. This implies that MFIs should not invest in non-financial assets such as supermarkets, pharmacies, residential housing development. Financing of total assets with saving deposits, borrowed funds and member share capital should not exceed 80 percent, 5 percent, 20 percent of total assets respectively. Institutional capital should be at least 10 percent of total assets of MFIs (Richardson 2002). Institutional capita comprises of regulatory reserves, other reserves, monetary donations and grants, and undivided earnings. In the case of cooperatives, ownership share capital is not included in the institutional capital. Share capital is withdrawable upon the termination of the membership and in some case it is used to secure the loan. The ratio of institutional capital to total assets measures the capital adequacy of MFIs. At least it should not come down below 10 percent of total assets (WOCCU 2002). But in our country, capital adequacy is measured in term of the percent of core capital and total capital on risk adjusted assets of cooperatives (NRB 2002). As stated earlier, this is in the same line of other FIs. An MFI's financial structure is said effective when assets financed by saving deposits generate sufficient income to pay market interest rates on savings, cover operating costs, and maintain capital adequacy (Evans and Branch 2002).

Asset Quality (A): Quality of assets of cooperative affects its earning power. Investment in non-earning assets and increase in the assets at risk deteriorate the earning power of a cooperative, decrease the institutional capital, and finally lead it to the liquidation. PEARLS uses these three indicators-delinquency ratio, percent of non-earning ratio and financing of none-earning assets to identify the impact of non-earning assets (Richardson 2002). Delinquency ratio measures the delinquency rate of the total loan portfolio. It is the most important indicator of the quality of assets. The higher delinquency ratio implies more severity in the financial condition and presence of higher risk to the member-client savings. This ratio should not exceed 5 percent of the total gross loan portfolio.

The second indicator of asset quality measures the percentage of investment of MFIs in non-earning assets. Sometime, MFIs have to invest their funds in such assets to improve their physical image and attract the new member-clients. In the long run, they can attract more new member-clients, increase the member share capital and saving deposits, and finally increase the total assets. All these result in the low percent of investment in nonearning assets in the long-run. Thus, increase in the percent of non-earning assets should be temporary. The higher the ratio, the more difficult to generate sufficient earnings to cover the operating cost of MFIs and distribute the dividend to their members. So, MFIs should maintain the minimum level of their investment in non-earning assets. Total investment in non-earning assets of MFIs should not exceed 5 percent of their total assets.

As stated earlier, increase in non-earning assets deteriorates the earning power of MFIs. In order to neutralize the negative effect of such assets on the profitability through weakening the earning power, they should be financed with explicit net zero cost funds 
such as institutional capital, transitory capital and non-interest bearing liabilities. So, MFIs should finance 100 percent of non-earning assets to do away the negative effect on their profitability.

Rates of Return and Costs $(\mathbf{R})$ : This component of PEARLS system segregates the different components of yield on investment and evaluates the efficiency of management in terms of controlling of operating costs. Further, management can rank the different components of investments by comparing the yields on different components of the investments and identify the problem area of operational cost of MFIs. The indicators of this component are categorized into two categories: indicators relating to rates of return and operational costs. $\mathrm{R}_{1}, \mathrm{R}_{2}, \mathrm{R}_{3}, \mathrm{R}_{4}, \mathrm{R}_{8}$ and $\mathrm{R}_{12}$ fall in the first category and $\mathrm{R}_{5}, \mathrm{R}_{6}, \mathrm{R}_{7}, \mathrm{R}_{9}, \mathrm{R}_{10}$, and $\mathrm{R}_{11}$ fall in the second one (for detail refer to Appendix 1 ). The indicators of the first category measure the return on the different components of investment: loan portfolio, liquid investments, financial investments, non-financial investments, and return on total assets. In general, the WOCCU model compares the calculated returns to the entrepreneurial return and market rate of returns. In the same vein, cost of the funds like cost of the funds raised from the saving deposits, external credit, cost of member share capital also are compared with the market rates. Thus, this component evaluates the yields on the investment and financial costs paid on member savings, member shares, and external loans.

Liquidity (L): Maintaining the high liquidity affects the profitability adversely. Since, investment in the liquid assets yields very low rate of return. Some of the liquid assets such as cash on hand and checking account yield nothing at all. Therefore, MFIs should maintain proper balance between the liquidity and profitability. Traditionally, liquidity is viewed in terms of cash available to lend in a financial institution. Lending in a financial institution is a variable under the control of the management of an FI. But bringing about the withdrawable saving deposits in an FI has added the new dimension to the concept of the liquidity. In this perspective, liquidity implies the cash required for possible withdrawals of saving deposits. This variable — cash required for possible withdrawals of saving deposits, is beyond the control of the management of MFIs. So, the management of liquidity has turned out more complicated in MFIs. It should maintain adequate liquidity reserves for its sound financial health. The PEARLS system analyzes the liquidity of MFIs from two perspectives: total liquidity reserves and idle liquid funds. In the first perspective, the adequacy of cash reserves to satisfy deposit withdrawal requests is measured. Cash reserve after paying the total short-term payables less than 30 days should not be less than 15 percent of the total saving (refer to Appendix 1). In the second perspective, liquidity is measured to analyze whether MFIs have complied with the reserve requirement of regulatory authority. PEARLS system uses two ratios-liquidity reserve to saving deposits and non-earning liquid assets to total assets. According to the WOCCU model, MFIs should maintain 10 percent liquidity reserve of the saving deposit and have non-earning assets less than 1 percent of total assets. Signs of Growth (S): Growth of assets accompanied with sustained profitability is the key to the successful MFIs. PERALS system links the growth to profitability and other key areas. Growth is measured in these key areas: total assets, loan, liquid investment, financial investment, saving deposits, external credit, member share capital, institutional capital, and number of members. Growth in total assets is one of the most important ratios. Strong and consistent growth in total assets brings about the improvements in many key ratios. Annual 
growth rate should be more than inflation rate.

Loan portfolio is the most important asset of FIs. Growth in total loan should keep the same pace of the growth in the total assets. Lower growth rate in loan portfolio relative to the growth in total assets implies the investment of funds in less profitable assets and conversely the higher growth in loan portfolio signals good probability of maintenance of profitability. Growth in saving deposits affects the growth in loan portfolio, and total assets. It affects other key areas of MFIs positively. But high growth in saving deposits may be turned out burdensome if MFIs is not able to mobilize the deposits to profitable investment. The WOCCU model is deemphasizing the member share capital. But some credit unions may not able to promote the saving deposits. Such unions are highly dependent on member capital. So, high growth rate in share capital reflects the weak marketing program.

Growth in institutional capital reflects the profitability of MFIs. It is difficult in adding to institutional capital for an MFI with low earning. Constant growth rate or declining growth rate indicates a problem with earnings. Sustainable institutional capital growth rate, usually greater than the growth in total assets, shows the robustness of an MFI.

\section{Methodology and Data}

Primarily, this study is based on the financial data disclosed by PRCSL in its annual reports. Secondarily, it is based on the off-financial statement information and data extracted from the subsidiary books and explored during the discussion with managerial level employees and chairman of PRCSL. This study covers the time horizon of five years (fiscal year 2001/02 through 2005/06). It has analyzed the soundness of financial health of study unit in the framework of PEARLS. Indicators of PEARLS are calculated strictly following the principles and guidelines given in the Toolkit Series Number 4 and Technical Guide to PEARLS available on line at official website of the WOCCU (for details of indicators refer to Appendix 1). Out of 44 indicators of six components of PEARLS system, 35 indicators are used to evaluate the financial health of PRCSL. Since the data on the study unit do not permit to work out 9 indicators of different components. Study unit does not have the policy of writing off the delinquent loans. So, only 3 indicators: $\mathrm{P}_{1}, \mathrm{P}_{2}$ and $\mathrm{P}_{6}$, of first component have been worked out.

PRCSL does not have non-financial investment during the study period. So, it is not possible to work out the indicators related to non-financial investment: E4, R4, and G4. It has invested in financial assets but has not received any dividend and interest during the study period. It is running under the jurisdiction of Cooperative Act, 1991 and Cooperative Regulation, 1992 and has not obtained the license from NRB. So, like other cooperatives licensed for limited banking service, it does not need to comply with any regulation of reserve requirements. Similarly, it does not have external loan capital in the first four fiscal years. So, $\mathrm{R}_{3}, \mathrm{~L}_{2}$ and $\mathrm{G}_{6}$ have not been worked out. Thus, this study has used 3 indicators of protection: $\mathrm{P}_{1}, \mathrm{P}_{2}$ and $\mathrm{P}_{6} ; 8$ indicators of effective financial structure: $\mathrm{E}_{1}, \mathrm{E}_{2}, \mathrm{E}_{3}, \mathrm{E}_{5}, \mathrm{E}_{6}, \mathrm{E}_{7}$, $E_{8}$, and $E_{9} ; 3$ indicators of asset quality: $A_{1}, A_{2}$ and $A_{3} ; 10$ indicators of rates of return and costs: $\mathrm{R}_{1}, \mathrm{R}_{2}, \mathrm{R}_{5}, \mathrm{R}_{6}, \mathrm{R}_{7}, \mathrm{R}_{8}, \mathrm{R}_{9}, \mathrm{R}_{10}, \mathrm{R}_{11}$ and $\mathrm{R}_{12}$; 2 indicators of liquidity: $\mathrm{L}_{1}$ and $\mathrm{L}_{3}$; and finally 9 indicators of sign of growth: $\mathrm{G}_{1}, \mathrm{G}_{2}, \mathrm{G}_{3}, \mathrm{G}_{5}, \mathrm{G}_{7}, \mathrm{G}_{8}, \mathrm{G}_{9}, \mathrm{G}_{10}$ and $\mathrm{G}_{11}$. 


\section{Analysis of Financial Health of PRCSL}

This section analyzes the indicators of the financial health of PRCSL in the PEARLS framework. As stated in Methodology, all indicators of the financial health of PRCSL have not been worked out and analyzed, only the indicators permitted by available financial data have been used to analyze its financial health. The ensuing section presents the analysis of different indicators of each component of PEARLS.

\subsection{Protection}

Protection to the saving of the member-client in a cooperative can be made by providing the adequate protection to the assets. This can be made by providing the sufficient allowances for loan losses. As stated in the Theoretical Prescription, if the provision for loan losses is not made adequately, asset value is inflated and fictitious earnings are reported. In such a condition, cooperative may impair the saving deposits by giving away the dividend and bonus from institutional capital and paying income tax to the government for fictitious income. So, regulatory authority and management should regularly monitor the adequacy of allowances for loan losses to protect the saving deposits and retain the confidence of depositors, win the confidence of potential depositors, and prevent the potential financial crisis.

As stated earlier, PRCSL is out of the jurisdiction of NRB. So it does not have to comply with the directives of NRB issued with respect to the allowances for loan losses. Its regulation also does not have provision for allowances for loan losses. So, it has not followed the specified policy for loan loss provision. It has charged off the loan loss provision expenses to profit and loss account arbitrary. In the first year, it has not set aside the earning for allowance to loan losses and in other years, it has done arbitrary.

The WOCCU model prescribed that any credit union should provide 100 percent allowances for loan past due for more than one year. $\mathrm{P}_{1}$ is above 100 percent in all fiscal years. This implies that PRCSL has adequate provision to cover the bad debt losses. ${ }^{2}$ But $\mathrm{P}_{2}$ shows that loan loss provision of PRCSL is not adequate to cover the possible loan loss on substandard and doubtful loan. According to the WOCCU model, allowance for the loan delinquent from 1-12 months should be 35 percent of such loans. But, this ratio is far below the WOCCU standard. This implies that its assets are inflated, earnings are overstated, and savings are at risk. $\mathrm{P}_{6}$ also bolsters that savings are at risk. This indicator measures the relative worth of one unit of member-client saving after adjusting known and probable losses. $\mathrm{P}_{6}$ is considerably below the WOCCU standard.

Table 1: Indicators of Protection

\begin{tabular}{lcccccc}
\hline Indicators & Standard & $\mathbf{2 0 0 2}$ & $\mathbf{2 0 0 3}$ & $\mathbf{2 0 0 4}$ & $\mathbf{2 0 0 5}$ & $\mathbf{2 0 0 6}$ \\
\hline $\mathrm{P}_{1}:$ Allowances for Loan losses/Delinquency & $100 \%$ & 0 & 139.72 & 248.94 & 228.68 & 226.81 \\
$>12$ months & & & & & & \\
$\mathrm{P}_{2}:$ Net Allowance for Loan & $35 \%$ & - & 3.53 & 13.50 & 8.63 & 9.32 \\
$\begin{array}{l}\text { Losses/Delinquency of 1-12 months } \\
\mathrm{P}_{3}: \text { Total Write-off Delinquency Loans }>\end{array}$ & $100 \%$ & $\mathrm{NA}$ & $\mathrm{NA}$ & $\mathrm{NA}$ & $\mathrm{NA}$ & $\mathrm{NA}$ \\
12 months & & & & & & \\
$\mathrm{P}_{4}:$ Annual Loan Write-off/Average Loan & Minimal & $\mathrm{NA}$ & $\mathrm{NA}$ & $\mathrm{NA}$ & $\mathrm{NA}$ & $\mathrm{NA}$
\end{tabular}

${ }^{2}$ The loan past due for more than one year is considered as bad debt. 
Financial Health Check-up of Pokhara Royal Co-operative Society Limited in the Framework of PEARLS

\begin{tabular}{lcccccc}
\hline $\mathrm{P}_{5}:$ Accumulated Loan Recoveries/ & $100 \%$ & NA & NA & NA & NA & NA \\
$\begin{array}{l}\text { Accumulated Loan Write-off } \\
\mathrm{P}_{6}: \text { Net Value of Assets/Total Shares and }\end{array}$ & $>=110 \%$ & 95.4 & 91.51 & 97.95 & 95.01 & 97.27 \\
Deposits & & & & & & \\
\hline
\end{tabular}

Source: Worked out from the data extracted from annual reports and loan ledger.

Though more than 5 percent of its loan portfolio is at risk (refer to Table 3 ), it does not have the policy of writing off loan. The reason behind this is the policy of taking the collateral for 100 percent of loan amount and management of PRCSL believes that 100 percent due amount will be recovered by selling out the collaterals. So, this policy of not writing off the delinquent loan does not provide the data to work out $\mathrm{P}_{3}, \mathrm{P}_{4}$ and $\mathrm{P}_{5}$.

\subsection{Effective Financial Structure}

This component of PEARLS focuses on the effective management of sources and uses of funds of MFIs. Management of use of funds seems satisfactory during the study period. Indicators that signals the effective use of funds: $E_{1}, E_{2}, E_{3}$ and $E_{4}$, are within the range fixed by the WOCCU model. $\mathrm{E}_{1}, \mathrm{E}_{2}, \mathrm{E}_{3}$ and $\mathrm{E}_{4}$ indicate that PRCSL has invested most of its funds in more productive assets, and less in non-earning and less productive assets during the study period. It has minimal level of liquid investment and financial investment, and no non-financial investment during the study period. Majority of the indicators of management of sources of funds show that PRCSL has managed the sources of funds effectively during the study period. $\mathrm{E}_{5}, \mathrm{E}_{6}$ and $\mathrm{E}_{7}$ are within the range of the WOCCU model but $\mathrm{E}_{8}$ and $\mathrm{E}_{9}$ are far below the benchmarks. PRCSL has financed around 75 percent to 80 percent of its assets with saving deposits which is within the range prescribed by the WOCCU model. This implies that PRCSL has effective marketing programs and is well on its way to achieving financial independence. $\mathrm{E}_{6}$ also bolsters that it has effective marketing program to sell its saving products and gained financial independency.

\section{Table 2: Indicators of Effective Financial Structure}

\begin{tabular}{lcccccc}
\hline Indicators & Standard & $\mathbf{2 0 0 2}$ & $\mathbf{2 0 0 3}$ & $\mathbf{2 0 0 4}$ & $\mathbf{2 0 0 5}$ & $\mathbf{2 0 0 6}$ \\
\hline $\mathrm{E}_{1}:$ Net Loan/Total Assets & $70-80 \%$ & 71.96 & 80.73 & 79.58 & 82.77 & 78.44 \\
$\mathrm{E}_{2}:$ Liquid investments/Total Assets & Max 20\% & 11.68 & 8.22 & 11.65 & 9.30 & 11.92 \\
$\mathrm{E}_{3}:$ Financial Investments/Total Assets & Max 10\% & 0.13 & 0.06 & 0.04 & 0.03 & 0.11 \\
$\mathrm{E}_{4}:$ Non-financial Investments/Total Assets & $0 \%$ & - & - & - & - & - \\
$\mathrm{E}_{5}:$ Saving Deposits/Total Assets & $70-80 \%$ & 75.20 & 79.59 & 79.33 & 79.92 & 78.14 \\
$\mathrm{E}_{6}:$ External Credit/Total Assets & Max 5\% & - & - & - & - & 0.45 \\
$\mathrm{E}_{7}:$ Member Share Capital/Total Assets & $10-20 \%$ & 17.71 & 13.89 & 11.66 & 9.56 & 10.63 \\
& Minimum & & & & & \\
$\mathrm{E}_{8}:$ Institutional Capital/Total Assets & $10 \%$ & 0.78 & 1.26 & 1.47 & 2.44 & 2.78 \\
$\mathrm{E}_{9}:$ Net Institutional Capital/Total Assets & Minimum & & & & & \\
& $10 \%$ & $(1.87)$ & $(1.40)$ & 0.47 & 0.43 & 1.36 \\
\hline
\end{tabular}

Source: Worked out from the data extracted from annual reports.

Member share capital also is within the range of the WOCCU model. Both $\mathrm{E}_{8}$ and $\mathrm{E}_{9}$ are far below the WOCCU benchmark. Institutional capital is the second line of defense to 
absorb unexpected losses. As stated earlier in Theoretical Prescription, institutional capital includes all legal reserves and surplus created either from the accumulation of net income or from capital donation. Low level of $\mathrm{E}_{8}$ implies that PRCSL has set aside insufficient reserves and retained low level of earning in the business. $\mathrm{E}_{9}$ is negative in the first two years and far below the WOCCU benchmarks in the consecutive years of the study period. The negative $\mathrm{E}_{9}$ shows that its institutional capital is not enough even to cover 100 percent of delinquent loan greater than 1 year and 35 percent of delinquent loan from 1 to 12 months. This analysis of institutional capital concludes that second line of defense of PRCSL also is weak during the study period.

\subsection{Asset Quality}

Asset quality is another indicator of financial health of a cooperative. Loan portfolio occupies the largest proportion in total assets of MFIs. The largest source of risk of any FI resides in its loan portfolio. Thus, risk, in case of a FI, largely depends on the quality of loan portfolio. The WOCCU has designed 3 indicators to measure asset quality: $A_{1}, A_{2}$ and $A_{3}$. $\mathrm{A}_{1}$ measures the proportion of delinquent loan in the gross loan portfolio. $\mathrm{A}_{1}$ of PRCSL in all years is greater than 5 percent. This reveals that assets quality of PRCSL is below the standard prescribed by the WOCCU model. The reason behind the delinquent ratio above the WOCCU benchmark is the psychology of management about the secured loans. As the information explored during the discussion with the Chairman and Secretary of PRCSL, all loans are backed up by collaterals and they can recover the loan by selling out the collaterals. Due to this psychology of management, PRCSL does not write off the loan and take the stringent action against defaulters.

Similarly, the quality of assets can be measured in term of the proportion of nonearning assets such as cash, non-interest earning money checking accounts, account receivable, fixed assets, to the total assets of a cooperative. Such assets should not exceed 5 percent of total assets of a cooperative. But in the case of PRCSL, percent of such assets is in excess to 5 percent of its total assets during the study period. Proportion of non-earning assets has decreased in each year during the first four years but it has soared up to 8.61 percent in the last year of the study period. This is because of the heavy investment in land and building. Land and building occupies around 79 percent of total non-earning assets in 2006.

Table 3: Indicators of Asset Quality

\begin{tabular}{lcccccc}
\hline Indicators & Standard & $\mathbf{2 0 0 2}$ & $\mathbf{2 0 0 3}$ & $\mathbf{2 0 0 4}$ & $\mathbf{2 0 0 5}$ & $\mathbf{2 0 0 6}$ \\
\hline $\mathrm{A}_{1}:$ Total Loan Delinquency/Gross Loan & $<=5 \%$ & 7.02 & 11.24 & 6.31 & 9.65 & 7.48 \\
Portfolio & & & & & & \\
$\mathrm{A}_{2}:$ Non-earning Assets/Total Assets & $<=5 \%$ & 16.23 & 9.94 & 7.68 & 6.74 & 8.61 \\
$\mathrm{~A}_{3}$ : Net Zero Cost Funds/Non-earning Assets & $>200 \%$ & 26.14 & 42.71 & 90.14 & 111.34 & 93.00 \\
\hline
\end{tabular}

Source: Worked out from the data extracted from annual reports and loan ledger.

Increase in non-earning assets deteriorates the overall profitability of an MFI. If they are financed with net zero cost funds, investment in non-earning assets does not affect the profitability adversely. In general, non-earning assets should be financed with zero cost funds. The decrease in net zero cost funds to non-earning ratio shows deterioration of asset quality and vice versa. It should not come down below 200 percent of total non-earning 
assets of a cooperative. In the case of PRCSL, this ratio is far below this benchmark of the WOCCU model. The fundamental reason behind this is the low level of institutional capital of PRCSL during the study period.

\subsection{Rates of Return and Costs}

As stated in Theoretical Prescription, indicators of this component are categorized into two categories: indicators relating to rates of return and operational costs. R 1 measures the yield on the loan portfolio. For the purpose of calculation of $\mathrm{R}_{1}$, interest income is inclusive to commission, fee, and penalty charges; and exclusive to premium on loan insurance. According to the WOCCU model, $\mathrm{R}_{1}$ should be greater than the entrepreneurial rate. Entrepreneurial return covers interest expenses, cost of operation and administration. In addition, it should earn enough to contribute to capital levels which maintain institutional capital at least 10 percent of total assets. As stated earlier, level of institutional capital is quite below the level fixed by WOCCU model and earning of PRCSL is not enough to contribute to institutional capital to maintain 10 percent of total assets. Though $\mathrm{R}_{1}$ is seemed quite high during the study period, yet loan yield is not enough to cover the entrepreneurial return. Its return on liquid asset is quite low and on financial investment is zero during the study period. It has not invested its funds in non-financial assets during the study period.

Table 4: Indicators of Rates of Return and Costs

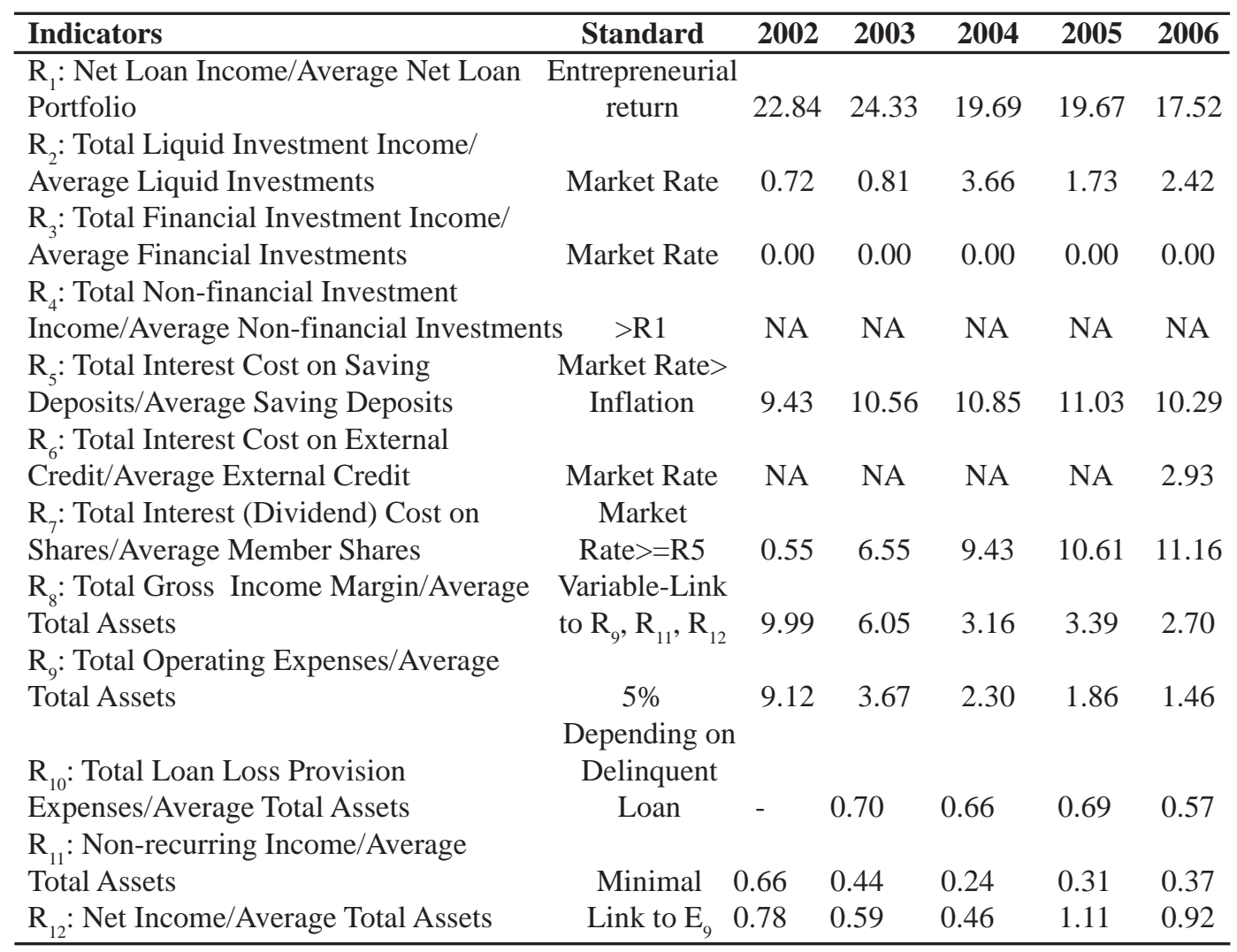

Source: Worked out from the data extracted from annual reports and loan ledger. 
$\mathrm{R}_{8}$ measures whether cooperative has generated sufficient income to cover all operating expenses and allowances for loan losses and provided for adequate increases in institutional capital. $\mathrm{R}_{9}$ shows that management is increasing its efficiency in controlling the operating expenses during the study period. But $\mathrm{R}_{8}$ is decreasing year by year. The reason behind this is increasing financial cost and decreasing income from interest relatively during the study period. This is the reason why, as analyzed earlier, PRCSL has not earned sufficient to contribute to the institutional capital required to maintain at least 10 percent of total assets. But the increasing $\mathrm{R}_{7}$ shows that PRCSL is distributing the dividend by impairing the institutional capital and risking the member-client saving during the study period. But the lower financial cost on member share capital shows that PRCSL is not yielding return enough to compensate the risk born by member-client on share capital. Theoretically, financial cost on member share capital should be higher than that of debt capital. But, here, financial cost on saving deposit is higher than that of share capital. This concludes that PRCSL is not compensating its member-client for investing in share capital. The fluctuating $R_{12}$ shows the inconsistency in the earning and institutional capital building capacity during the study period.

\subsection{Liquidity (L)}

As stated earlier, PRCSL is out of the jurisdiction of NRB. It does not need to comply with any mandatory liquidity reserve. So, it does not maintain such liquidity reserve. Investment in non-earning liquid assets increases the liquidity position of a cooperative but it does not earn anything. So, investment in such assets should be minimal. According to the WOCCU model, it should not exceed 1 percent of total assets. But non-earning liquid assets of PRCSL is greater than this limit during the study period. Accrued interest has occupied the considerable amount of non-earning liquid assets. The percent of accrued interest ranges from 19 percent to 65 percent of non-earning liquid assets during the study period. The considerable amount of accrued interest in both relative and absolute term in total nonearning liquid assets threats the liquidity position of PRCSL further.

Table 5: Indicators of Liquidity

\begin{tabular}{lcccccc}
\hline Indicators & Standard & $\mathbf{2 0 0 2}$ & $\mathbf{2 0 0 3}$ & $\mathbf{2 0 0 4}$ & $\mathbf{2 0 0 5}$ & $\mathbf{2 0 0 6}$ \\
\hline $\mathrm{L}_{1}$ : Short-term Investment + Liquid Assets- & Minimum & & & & & \\
Short-term Payables/Total Saving Deposits & $15 \%$ & 20.06 & 12.94 & 16.41 & 12.37 & 10.54 \\
$\mathrm{~L}_{2}:$ Liquidity Reserve/Saving Deposits & $10 \%$ & - & - & - & - & - \\
$\mathrm{L}_{3}$ : Non-earning Liquid Assets/Total Assets & $<1 \%$ & 9.52 & 6.53 & 6.54 & 5.78 & 1.77 \\
\hline
\end{tabular}

Source: Worked out from the data extracted from annual reports.

$\mathrm{L}_{3}$ measures the adequacy of the liquid cash reserves to satisfy deposit withdrawal request after paying all immediate obligation less than 30 days. $\mathrm{L}_{3}$ is fluctuating during the study period. It is below the benchmark of the WOCCU model in 2003, 2005 and 2006. On the whole, liquidity position is deteriorating. The deteriorating liquidity position hints that PRCSL may fail to satisfy the deposit withdrawal request and come across the cooperative run problem. 


\subsection{Sign of Growth}

Sustainable growth in different financial variables of a cooperative is important to profitability. Growth in none of the key variables is smooth during the study period. The fluctuating growth in key variables implies that PRCSL has no strategy for sustainable growth in its business. Growth rates in gross loan $\left(G_{1}\right)$, saving deposits $\left(G_{5}\right)$, institutional capital $\left(\mathrm{G}_{8}\right)$ and total assets $\left(\mathrm{G}_{11}\right)$ are keys to the profitability. Unless and until saving deposits and institutional capital grow at sustainable rate, gross loan and total assets can not grow. Gross loan is growing at decreasing rate during the study period. As stated earlier, $\mathrm{E}_{1}$ is within the range prescribed by the WOCCU model during the study period. So, $\mathrm{G}_{1}$ is not below the benchmark.

Table 6: Indicators of Sign of Growth

\begin{tabular}{|c|c|c|c|c|c|c|}
\hline Indicators & Standard & 2002 & 2003 & 2004 & 2005 & 2006 \\
\hline $\mathrm{G}_{1}$ : Growth in Gross Loan & Depending on E1 & - & 130.15 & 66.24 & 51.96 & 55.88 \\
\hline $\mathrm{G}_{2}$ : Growth in Liquid Investments & Depending on E2 & - & 42.51 & 138.86 & 16.58 & 111.25 \\
\hline $\begin{array}{l}\mathrm{G}_{3}^{2} \text { : Growth in Financial Investment } \\
\mathrm{G}^{2} \cdot \text { Growth in Non-financial }\end{array}$ & Depending on E3 & - & - & 8.57 & 10.20 & 531.58 \\
\hline Invest & & - & - & - & - & - \\
\hline $\mathrm{G}_{5}: \mathrm{G}_{1}$ & & - & 114.38 & 68.04 & 47.07 & 61.20 \\
\hline $\mathrm{G}_{6}^{5}: \mathrm{Gro}$ & & - & - & - & - & - \\
\hline $\mathrm{G}_{7}^{6}$ : Growth in Member Shares & g E7 & - & 58.82 & 41.60 & 19.60 & 83.45 \\
\hline $\mathrm{G}_{8}:$ Growth in Institutional Capital & Depending E8 & - & 228.33 & 97.52 & 141.52 & 88.24 \\
\hline $\mathrm{G}_{0}$ : Growth in Net Institutional Capital & Depending E9 & - & 51.25 & $(156.52)$ & 35.14 & 416.72 \\
\hline $\mathrm{G}_{10}:$ Growth in founder Members & $>12 \%$ & - & 26.47 & - & - & 3.49 \\
\hline $\mathrm{G}_{10.2}^{10.1}$ : Growth in General Members & $>12 \%$ & - & 7.80 & 11.35 & 37.63 & 14.85 \\
\hline $\mathrm{G}_{11}:$ Growth in Total Assets & $>$ Inflation & - & 102.53 & 68.60 & 45.98 & 64.87 \\
\hline Annualized inflation rate & & 2.9 & 4.8 & 4.00 & 4.3 & $7.6^{*}$ \\
\hline
\end{tabular}

Source: Worked out from the data extracted from annual reports.

* Inflation rate based on the first eight months.

Saving deposits also are growing at decreasing rate. But in the last year of the study period, it has increased. Saving deposits to total assets ratio is within the prescribed range during the study period. Though $\mathrm{G}_{5}$ is decreasing drastically in 2004 and 2005, $\mathrm{E}_{5}$ suggests that it has not come down below the desirable level. Institutional capital also is increasing during the study period. It shows the profitability of the business. But E8 suggests that it is far below the desirable level. Growth in member share capital $\left(G_{7}\right)$ is also, in general, in decreasing trend. But $\mathrm{E}_{7}$ suggests that it is satisfactory during the study period. Theoretically, growth in total assets should exceed the inflation rate. Growth rate in the assets of PRCSL also has exceeded the inflation rate during the study period. So, on the whole, growth of PRCLS is satisfactory during the study period.

\section{Diagnoses}

5.1 PRCSL has made sufficient loan loss provision for bad debt loan but it has not made adequate provision to cover the possible loan losses from doubtful and sub-standard loan. So it does not have strong first line of defense against non-performing assets. 
5.2 PRCSL has invested most of its funds in more productive assets and less in non-earning and less productive assets, and managed the sources of funds effectively from saving deposits. But it has a weak institutional capital base as a second line of defense against non-performing assets

5.3 Percentages of delinquent loan ratio and non-earning assets are greater than the standard set by the WOCCU model. Similarly, percent of net zero cost funds is less than the set benchmark. All these suggest that quality of assets of PRCSL is not up to the standard as set by the WOCCU model.

5.4 Operation and administration expenses of PRCSL is within the set limit but the yield on loan is not enough to contribute to the capital levels which maintain the institutional capital at least 10 percent and pay the returns on member share capital. In other words, its earning is not sufficient to make the second line of defense against non-performing assets and pay attractive dividend on member share capital.

5.5 The increasing percent of accrued interest in total non-earning liquid assets and decreasing percent of liquid cash reserves to satisfy deposit withdrawal request show the deteriorating liquidity position of PRCSL and probability of cooperative run.

5.6 The highly fluctuating growth rates in key financial variables imply that PRCSL does not have sound strategy for sustainable growth in its business. But the signs of growth of key variables except to institutional capital show that it has achieved desirable growth during the study period. Finally, growth in institutional capital is not enough to build up the second line of defense against non-performing assets.

\section{ACKOWLEDGEMENTS}

I am highly indebted to Major Tulsi Prasad Gurung, Chairman, PRCSL for his kind permission to test the PEARLS system on financial data of PRCSL. Similarly, I am grateful to Mr. Bhim Gurung, Secretary, and Mr. Babu Ram Dhakal, Account Officer, PRCSL for providing annual reports and other supporting information. Finally, I would like to express heartfelt thanks to all employees for their cooperation in exploring the off-financial statement information and data required for this study.

\section{Appendix 1: PEARLS'S RATIOS}

P: Protection

$\mathrm{P}_{1}$ : Allowance for Loan Losses to Allowances Required for Loans delinquent > 1 Year

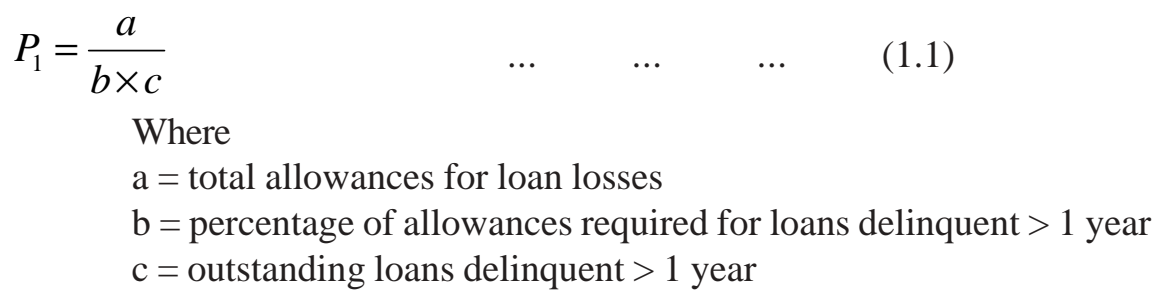


$\mathrm{P}_{2}$ : Net Allowance for Loan Losses to Delinquency of 1- 12 months

$$
\begin{aligned}
& P_{2}=\frac{a-b}{c} \\
& \text { Where } \\
& \begin{array}{l}
\mathrm{a}=\text { total allowances for loan losses } \\
\mathrm{b}=\text { loan allowance for loan delinquent }>1 \text { year } \\
\mathrm{c}=\text { delinquency of } 1-12 \text { months }
\end{array}
\end{aligned}
$$

$\mathrm{P}_{3}$ : Total Write-off Delinquent Loans to Delinquent Loans $>1$ Year

$$
\begin{gathered}
P_{3}=\frac{a}{b} \\
\text { Where } \\
\begin{array}{l}
\mathrm{a}=\text { total write-off delinquent loan } \\
\mathrm{b}=\text { loan delinquent }>1 \text { year }
\end{array}
\end{gathered}
$$

$\mathrm{P}_{4}$ : Annual Loan Write-Off to Average Loan Portfolio (Loan Write-off Ratio)

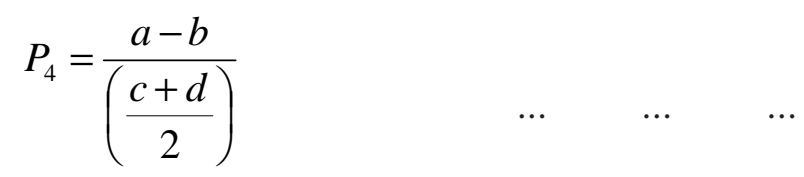

Where

$\mathrm{a}=$ accumulated loan written-off for current year

$\mathrm{b}=$ accumulated loan written of for previous year

$\mathrm{c}=$ gross loan portfolio as of current year-end

$\mathrm{d}=$ gross loan portfolio as of previous year-end

$\mathrm{P}_{5}$ : Accumulated Loan Recovery to Accumulated Loan Write-off (Recovery Ratio)

$$
P_{5}=\frac{a}{b}
$$

Where

$\mathrm{a}=$ accumulated loan recovery

$\mathrm{b}=$ accumulated loan written

$\mathrm{P}_{6}$ : Net Value of Assets to Total Share and Deposits (Solvency Ratio)

$$
P_{6}=\frac{a}{b}
$$

Where

$\mathrm{a}=$ net value of assets, and it is given by Model (1.6.1)

$\mathrm{b}=$ sum of total savings and total share capital 
Net Value of Assets

$$
\begin{aligned}
& a=[(c+d)-(e+f+g+h)] \\
& \text { Where } \\
& \mathrm{c}=\text { total assets } \\
& \mathrm{d}=\text { allowances for risky assets } \\
& \mathrm{e}=\text { total loan loss provision for delinquent loan } \\
& \mathrm{f}=\text { total liabilities } \\
& \mathrm{g}=\text { problem assets } \\
& \mathrm{h}=\text { total deposits }
\end{aligned}
$$

\section{E: Effective Financial Structure}

$\mathrm{E}_{1}$ : Net Loan to Total Assets Ratio

$$
\begin{aligned}
& \qquad \ldots \\
& \text { Where } \\
& \mathrm{a}=\text { gross loan portfolio } \\
& \mathrm{b}=\text { allowances for risky assets (total loan loss provision) } \\
& \mathrm{c}=\text { total assets }
\end{aligned}
$$

$\mathrm{E}_{2}$ : Liquid investment to Total Assets Ratio

$$
\begin{aligned}
& E_{2}=\frac{a}{c} \\
& \text { Where } \\
& \quad \mathrm{a}=\text { total liquid investment } \\
& \mathrm{c}=\text { total assets }
\end{aligned}
$$

$\mathrm{E}_{3}$ : Financial Investment to Total Assets Ratio

$$
\begin{array}{lllll}
E_{3}=\frac{a}{c} & \ldots & \ldots & \ldots
\end{array}
$$

Where

$\mathrm{a}=$ total financial investment

$\mathrm{c}=$ total assets

$\mathrm{E}_{4}$ : Non-financial Investment to Total Assets Ratio

$$
\begin{aligned}
& E_{4}=\frac{a}{c} \\
& \text { Where } \\
& \begin{array}{l}
\mathrm{a} \\
=\text { total non-financial investment } \\
\mathrm{c}=\text { total assets }
\end{array}
\end{aligned}
$$

$\mathrm{E}_{5}$ : Saving Deposits to Total Assets Ratio 


$$
\begin{aligned}
& E_{5}=\frac{a}{c} \\
& \quad \begin{array}{l}
\text { Where } \\
\mathrm{a}=\text { total saving deposits } \\
\mathrm{c}=\text { total assets }
\end{array}
\end{aligned}
$$

$\mathrm{E}_{6}$ : External Credit to Total Assets Ratio

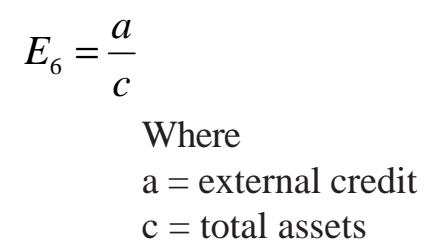

$\mathrm{E}_{7}$ : Member Share Capital to Total Assets Ratio

$$
\begin{aligned}
& E_{7}=\frac{a}{c} \\
& \text { Where } \\
& \quad \begin{array}{l}
\mathrm{a}=\text { member share capital } \\
\mathrm{c}=\text { total assets }
\end{array}
\end{aligned}
$$

$\mathrm{E}_{8}$ : Institutional Capital to Total Assets Ratio

$$
\begin{aligned}
& E_{8}=\frac{a}{c} \\
& \quad \text { Where } \\
& \quad \mathrm{a}=\text { institutional capital } \\
& \mathrm{c}=\text { total assets }
\end{aligned}
$$

$\mathrm{E}_{9}$ : Net Institutional Capital to Total Assets Ratio

$$
\begin{aligned}
& E_{9}=\frac{a}{c} \quad \ldots \quad \ldots
\end{aligned}
$$

\section{Net Institutional Capital (a)}

$$
a=(d+e)-(f+.35 g)
$$

Where

$\mathrm{d}=$ institutional capital

$\mathrm{e}=$ allowances for risk assets

$\mathrm{f}=$ outstanding loans delinquent $>1$ year

$\mathrm{g}=$ outstanding loans delinquent $<1$ year 
A: Asset Quality

$\mathrm{A}_{1}$ : Total Loan Delinquency to Total Loan Portfolio

Where

$\mathrm{a}=$ total delinquent loan (loan past due for one month and more than one month)

$\mathrm{b}=$ total loan portfolio

$A_{2}$ : Total Non-earning Assets to Total Assets Ratio

$$
A_{2}=\frac{a}{b}
$$

Where

$\mathrm{a}=$ total non-earning assets, and it is given by (3.2.1)

$\mathrm{b}=$ total assets

Total Non-earning Assets (a)

$$
a=(c+d+e+f+g+h
$$

Where

$\mathrm{c}=$ cash on hand

$\mathrm{d}=$ non-interest bearing monetary checking account

$\mathrm{e}=$ account receivables

$\mathrm{f}=$ Assets in liquidation

$\mathrm{g}=$ fixed assets (land and building, equipment etc.)

$\mathrm{h}=$ prepaid expenses and other deferrals

\section{$A_{3}$ : Net Zero Funds to Total Non-earning Assets Ratio}

$$
A_{3}=\frac{a}{b}
$$

Where

$\mathrm{a}=$ net zero cost funds given by (3.3.1)

$\mathrm{b}=$ total non-earning assets

\section{Net Zero Cost Funds (a)}

$a=(c+d+e$

Where

$\mathrm{c}=$ total net institutional capital (refer to Model 2.9.1)

$\mathrm{d}=$ total transitory capital

$\mathrm{e}=$ total non-interest bearing liabilities 
R: Rates of Return and Costs:

$\mathbf{R}_{1}$ : Net Loan Income to Average Net Loan Ratio

$$
R_{1}=\frac{a-b}{\frac{c+d}{2}}
$$

Where

$\mathrm{a}=$ total loan income (including commission, fees and penalty interest)

$\mathrm{b}=$ insurance premium paid on loans

$\mathrm{c}=$ net loan portfolio as of current year-end

$\mathrm{d}=$ net loan portfolio as of last year-end

$\mathbf{R}_{2}:$ Liquid Investment Income to Average Liquid Investment Ratio

$$
R_{2}=\frac{a}{\frac{b+c}{2}}
$$

Where

$\mathrm{a}=$ total liquid investment income during the year

$\mathrm{b}=$ total liquid investment as of current year-end

$\mathrm{c}=$ total liquid investment as of last year-end

\section{$\mathbf{R}_{3}$ : Financial Investment Income to Average Financial Investment Ratio}

$$
R_{3}=\frac{a}{\frac{b+c}{2}}
$$

Where

$\mathrm{a}=$ total financial investment income during the year

$\mathrm{b}=$ total financial investment as of current year-end

$\mathrm{c}=$ total financial investment as of last year-end

\section{$R_{4}$ : Non-financial Investment Income to Average Non-financial Investment Ratio}

$$
R_{4}=\frac{a}{\frac{b+c}{2}}
$$

Where

$\mathrm{a}=$ total non-financial investment income during the year

$\mathrm{b}=$ total non-financial investment as of current year-end

$\mathrm{c}=$ total non-financial investment as of last year-end 


\section{$\mathbf{R}_{5}$ : Total Interest Cost on Saving Deposits to Average Saving Deposits Ratio}

$$
R_{5}=\frac{a}{\frac{b+c}{2}}
$$

Where

$\mathrm{a}=$ total saving deposit cost and it includes total interest paid on saving deposits, total interest premium paid on saving deposits, total tax paid by MFIs on saving deposit interest

$\mathrm{b}=$ total saving deposits as of current year-end

$\mathrm{c}=$ total saving deposits as of last year-end

\section{R $_{6}$ : Total Interest Cost on External Credit to Average External Credit Ratio}

$$
R_{6}=\frac{a}{\frac{b+c}{2}}
$$

Where

$\mathrm{a}=$ total interest paid on external credit (borrowed funds)

$\mathrm{b}=$ total external credits (borrowed funds) as of current year-end

$\mathrm{c}=$ total external credits (borrowed funds) as of last year-end

\section{$\mathbf{R}_{7}$ : Total Dividend on Share Capital to Average Member Share Capital Ratio}

$$
\begin{aligned}
R_{7}=\frac{a+b+c}{\frac{d+e}{2}} & \ldots \\
\text { Where } & \\
\mathrm{a} & =\text { total dividend paid on member shares } \\
\mathrm{b} & =\text { total insurance premium paid on member share capital } \\
\mathrm{c} & =\text { total taxes paid by MFI on dividend on share } \\
\mathrm{d} & =\text { total member share capital as of current year-end } \\
\mathrm{e} & =\text { total member share capital as of last year-end }
\end{aligned}
$$

\section{$\mathbf{R}_{\mathbf{8}}$ : Gross Margin to Average Total Assets Ratio}

$$
R_{8}=\frac{a}{\frac{b+c}{2}}
$$

Where

$\mathrm{a}=$ gross margin and it is given by Model (4.8.1)

$\mathrm{b}=$ total assets as of current year-end

$\mathrm{c}=$ total assets as of last year-end 


\section{Gross Margin (a)}

$$
\begin{aligned}
& a=(d+e+f+g+h)-(i+j+k) \\
& \quad \text { Where } \\
& \mathrm{d}=\text { loan interest income } \\
& \mathrm{e}=\text { liquid investment income } \\
& \mathrm{f}=\text { financial investment income } \\
& \mathrm{g}=\text { non-financial investment income } \\
& \mathrm{h}=\text { other income } \\
& \mathrm{i}=\text { interest cost of saving deposits } \\
& \mathrm{j}=\text { dividend cost of member share capital } \\
& \mathrm{k}=\text { interest cost of external credit (borrowed funds) }
\end{aligned}
$$

\section{$\mathbf{R}_{\mathbf{9}}$ : Operating Expenses to Average Total Assets Ratio}

$R_{9}=\frac{a}{b \mathbf{R}_{10}}:$ Total Loan Loss Provision Expenses to Average Total Assets Ratio

Where

$\mathrm{a}=$ total operating expenses excluding provision for loan losses

$b=$ total assets as of current year-end

$\mathrm{c}=$ total assets as of last year-end

2

$$
R_{10}=\frac{a}{\frac{b+c}{2}}
$$

Where

$\mathrm{a}=$ total loan loss provision expenses of current year for all risk assets

$\mathrm{b}=$ total assets as of current year-end

$\mathrm{c}=$ total assets as of last year-end

\section{$R_{11}$ : Total Non-recurring Income to Average Total Assets Ratio}

$$
\begin{aligned}
& R_{11}= \frac{a}{\frac{b+c}{2}} \\
& \text { Where } \\
& \mathrm{a}=\text { total non-recurring income of the current year } \\
& \mathrm{b}=\text { total assets as of current year-end } \\
& \mathrm{c}=\text { total assets as of last year-end }
\end{aligned}
$$


$R_{12}$ : Net Income to Average Total Assets Ratio

$$
R_{12}=\frac{a}{\frac{b+c}{2}}
$$

Where

$\mathrm{a}=$ net income after dividend

$\mathrm{b}=$ total assets as of current year-end

$\mathrm{c}=$ total assets as of last year-end

\section{L: Liquidity}

$\mathrm{L}_{1}$ : Short-term Investment + Liquid Assets - Short-term Payables to Total Saving Deposits Ratio

$$
\begin{aligned}
& L_{1}=\frac{(a+b)-c}{d} \\
& \begin{aligned}
\text { Where } \\
\mathrm{a}=\text { total earning liquid investment } \\
\mathrm{b}=\text { total non-earning liquid investment } \\
\mathrm{c}=\text { total short-term payables }<30 \text { days } \\
\mathrm{d}=\text { total saving deposits }
\end{aligned}
\end{aligned}
$$

\section{$\mathrm{L}_{2}$ : Liquid Reserve to Total Saving Deposits Ratio}

$$
\begin{aligned}
& L_{2}=\frac{(a+b)}{c} \ldots \\
& \text { Where } \\
& \text { a }=\text { total earning liquid reserves } \\
& \mathrm{b}=\text { total non-earning liquid reserves } \\
& \mathrm{c}=\text { total saving deposits }
\end{aligned}
$$

\section{$\mathrm{L}_{3}$ : Non-earning Liquid Assets to Total Assets Ratio}

$$
\begin{aligned}
& L_{3}=\frac{a}{b} \ldots \\
& \text { Where } \\
& \mathrm{a}=\text { total non-earning liquid assets } \\
& \mathrm{b}=\text { total assets }
\end{aligned}
$$




\section{S: Sign of Growth}

$\mathrm{S}_{1}$ : Growth in Gross Loan

$S_{1}=\left(\frac{a}{b}\right) \times 100-100$

Where

$\mathrm{a}=$ total gross loan as of current year-end

$\mathrm{b}=$ total gross loan as of last year-end

$\mathrm{S}_{2}$ : Growth in Liquid Investment

$S_{2}=\left(\frac{a}{b}\right) \times 100-100$

Where

$\mathrm{a}=$ total liquid investment as of current year-end

$\mathrm{b}=$ total liquid investment as of last year-end

\section{$\mathrm{S}_{3}$ : Growth in Financial Investment}

$S_{3}=\left(\frac{a}{b}\right) \times 100-100$

Where

$\mathrm{a}=$ total financial investment as of current year-end

$b=$ total financial investment as of last year-end

\section{$\mathrm{S}_{4}$ : Growth in Non-financial Investment}

$S_{4}=\left(\frac{a}{b}\right) \times 100-100$

Where

$a=$ total non-financial investment as of current year-end

$\mathrm{b}=$ total non-financial investment as of last year-end

$\mathrm{S}_{5}$ : Growth in Saving Deposits

$S_{5}=\left(\frac{a}{b}\right) \times 100-100$

Where

$\mathrm{a}=$ total saving deposits as of current year-end

$\mathrm{b}=$ total saving deposits as of last year-end 


\section{$\mathrm{S}_{6}$ : Growth in External Credit}

$S_{6}=\left(\frac{a}{b}\right) \times 100-100$

Where

$\mathrm{a}=$ total external credit as of current year-end

$\mathrm{b}=$ total external credit as of last year-end

\section{$\mathrm{S}_{7}$ : Growth in Member Share}

$$
\begin{aligned}
S_{7}=\left(\frac{a}{b}\right) & \times 100-100 \\
& \text { Where } \\
& \mathrm{a}=\text { total member share as of current year-end } \\
\mathrm{b} & =\text { total member share as of last year-end }
\end{aligned}
$$

\section{$\mathrm{S}_{8}$ : Growth in Institutional Capital}

$S_{8}=\left(\frac{a}{b}\right) \times 100-100$

Where

$\mathrm{a}=$ total institutional capital as of current year-end

$\mathrm{b}=$ total institutional capital as of last year-end

\section{$\mathrm{S}_{\mathbf{9}}$ : Growth in Net Institutional Capital}

$$
S_{9}=\left(\frac{a}{b}\right) \times 100-100
$$

Where

$\mathrm{a}=$ total net institutional capital as of current year-end

$\mathrm{b}=$ total net institutional capital as of last year-end

\section{$\mathrm{S}_{10.1}:$ Growth in Founder Members}

$$
S_{10.1}=\left(\frac{a}{b}\right) \times 100-100
$$

Where

$\mathrm{a}=$ total founder members as of current year-end

$\mathrm{b}=$ total founder members as of last year-end 
$\mathrm{S}_{10.2}:$ Growth in General Members

$$
\begin{aligned}
S_{10.2}= & \left(\frac{a}{b}\right) \times 100-100 \\
& \text { Where } \\
& \mathrm{a}=\text { total general members as of current year-end } \\
& \mathrm{b}=\text { total general members as of last year-end }
\end{aligned}
$$

\section{$\mathrm{S}_{11}:$ Growth in Total Assets}

$$
\begin{aligned}
S_{11}=\left(\frac{a}{b}\right) \times 100-100 & \ldots \\
& \text { Where } \\
& \mathrm{a}=\text { total assets as of current year-end } \\
\mathrm{b} & =\text { total assets as of last year-end }
\end{aligned}
$$

\section{REFERENCES}

Baral, Keshar J. 2005. Cooperatives in Nepal: Use and Effectiveness. A paper presented in the Interaction Program Organized by Royal Cooperative Ltd. , Pokhara.

Evans, Anna Cora and Brian Branch. 2002. "A Performance Monitoring System" A Technical Guide to PEARLS. Madison: WOCC. February 11, 2006. http://www.woccu.org/development/guide/ PEARLS_techguide.pdf.

Evan, Owns and others. 2000. "Macro prudential Indicators of Financial System Soundness." Occasional Paper 192. Washington DC: International Monetary Fund.

Government of Nepal, Ministry of Finance. 2006. Budget Speech of Fiscal Year 2006/007. Kathmandu: Ministry of Finance.

Nepal Rastra Bank (NRB). 2006. Financial Institutions Supervision Report, 2004-2005. Kathmandu: NRB, Financial Institution Supervision Department, Central Office.

Nepal Rastra Bank (NRB). 2005. Annual Bank Supervision Report, 2003-2004. Kathmandu: NRB, Bank Supervision Department, Central Office.

Nepal Rastra Bank (NRB). 2002. Directives to the Cooperatives Licensed for Limited Banking Services. Kathmandu: NRB, Bank Supervision Department, Central Office.

Richardson, David C. 2002. PEARLS Monitoring System: World Council of Credit Unions Tool Kits Series Number 4. Madison: World Council of Credit Unions.

Saunders, Anthony and Marcia Millon Cornett. 2004. Financial Markets and Institutions. New Delhi: Tata McGraw-Hill Publishing Company Limited.

Stauffenberg, Damian von, and others. 2003. Performance Indicators for Microfinance Institutions: Technical Guide, 3rd Edn. Washington D.C: MicroRate, and Inter-American Development Bank. Dec. 26, 2006. <www.iadb.org./sds/micr>.

WOCCU. 2002. Development Best Practices in Credit Unions Supervision: Regulatory Standards. Dec. 26, 2006. <http://www.woccu.org/best_practices/bp_files/1082038638regulatory.pdf> 